Komunike, Volume XI, No. 1, Juni 2019

\title{
PLURALISME AGAMA: STUDI TENTANG MAKNA DAN POLA KOMUNIKASI ANTAR UMAT ISLAM, HINDU DAN BUDHA DI PULAU LOMBOK. KOTA MATARAM
}

\author{
Hasyim Edi Rianto Saputra dan Muhtar Tayib \\ Email: ryanlbk09@gmail.com
}

\begin{abstract}
Abstrak
Isu pluralisme bukan lagi sebagai wacana yang diperdebatkan oleh para intelektual yangmasih berkisar pada hal-hal yang bersifat teoritisspekulatif tetapi sudah merambah pada hal yang lebih kongkrit yaitu praktis-pragmatis. Di Indonesia sendiri istilah pluralisme agama menjadi marak diperbincangkan setelah di usung oleh Nurcholis Madjid, Mukti Ali, Djohan Efendi. Dan pada tahun terakhir ini dilanjutkan oleh generasi berikutnya. Budhy Munawar Rahman dengan Paramadinanya, Ulil Abshar Abdalla dan kawan-kawan dengan Jaringan Islam Liberalnya (JIL). Terlebih lagi di pulau lombok yang terletak di provinsi NTB (Nusa Tenggara Barat), Degan asas skularisme ini masyarakat Sasak Lombok mampu menciptakan keharmonisan dan menciptakan pluralisme agama dan budaya menjadi indah. Sehingga tetap terjalin komunikasi antar umat beragama, adapun strategi yang digunakan yang masyarakat sasak menyebutnya "Panca Budaya Pluralis" antara lain: 1) Lewat budaya saling ajinin; 2) Lewat budaya saling pesilaq; 3) Lewat budaya saling pelayarin; 4) Lewat budaya saling ayowin.
\end{abstract}

Kata Kunci: Pluralisme, Komunikasi, Hindu, Budha

\section{A. Latar Belakang}

Manusia adalah mahkluk Allah

SWT yang diciptakan dalam bentuk

yang paling sempurna. Tetapi hidupnya, manusia membutuhkan

peran antar sesama manusia yang

biasa disebut dengan interaksi sosial.

dalam melaksanakan kelangsungan 
Komunike, Volume XI, No. 1, Juni 2019

Dalam kehidupannya, manusia lebih baik dari kita. Perbedaan bukan saja sebagai mahkluk adalah suatu yang lumrah kerena individual, tetapi manusia juga perbedaan itu kita bisa saling sebagai mahkluk sosial. Perannya mengenal dan saling melengkapi sebagai mahkluk individual, manusia bukan menjadikannya sumber konflik membutuhkan makan, minum, yang nantinya akan menimbulkan istirahat, tempat tinggal dan kesenjangan sosial antara umat kebutuhan lainnya. Sedangkan beragama di dalam kehidupan perannya sebagai mahkluk sosial, bernegara dalam ruang lingkup manusia membutuhkan orang lain Negara Kesatuan Republik guna melangsungkan kebutuhan Indonesia.

hidupnya. Sekumpulan manusia Kebebasan dalam Islam, yang hidup dan saling berinteraksi sungguh-sungguh dijunjung tinggi. satu dengan yang lain serta Justru kepada kebebasan itulah membentuk suatu sistem tatanan terletak perbedaan asasi manusia hidup dalam suatu tempat tinggal antara makhluk-makhluk yang lain. atau wilayah inilah yang nantinya Isyarat kebebasan itu, bahkan telah disebut dengan masyarakat. mulai muncul sejak proses paling

Di dalam al-Qur'an surah al- awal dari penciptaan manusia. Hujarat ayat 13, menjelaskan Selain memberikan kebebasan tentang keadaan sosial masyarakat penuh kepada manusia untuk yang dimana kita diciptakan menentang atau tunduk kepada bersuku-suku dan berbangsa untuk perintah tuhannya, al-Qur'an saling mengenal dan tidak saling membuka kesempatan kepada menjatuhkan. Karena tidakmenutup siapapun yang merasa mampu kemungkinan orang yang kitahina untuk menguji dan menandingi kitab 
suci itu ini terdapat dalam surah alBaqarah ayat 23, dengan ini menunjukan betapa ajaran Islam sesungguhnya merupakan ajaran yang sangat terbuka. ${ }^{1}$ Bukan saja untuk dipelajari bahkan untuk ditandingi. Petunjuk Islam sangat jelas pemilihan seorang terhadap suatu agama haruslah berdasarkan kemauan sendiri dan kesukarelaan, bukan karena adanya keterpaksaan baik secara fisik maupun sugestif dan dalam segala manifestasinya. Terhadap mereka yang berlainan agama, Islam mengajarkan sikap yang sangat lugas oleh sebab ini tidak ada alasan untuk menciptakan standar ganda pada masing-masing penganut agama.

Islam telah mengajarkan kebebasan bagi manusia yang ada di muka bumi ini sebagaimana teks dalam Qur'an "Islam agama rohmatan lil alamin", dengan dasar

1 Tarmizi Taher dan Moch. Basofi Soedirman, Ham Dan Pluralisme Agama, (Surabaya: PSKS, 1997), hlm. 33. ini tidak ada paksaan bagi seorang dalam beragama, berhak memeluk agama sesuai dengan kepercayaannya masing-masing, terlebih lagi di Negara Indonesia yang terkenal dengan multicultural agama dan budaya dengan inilah muncul semboyan "Bhineka Tunggal Ika”. Sebagaiamana yang tercantum dalam UUD 1945 dan pasal 29 ayat 2 sudah sangat jelas di tuliskan tidak ada paksaan bagi seorang dalam memeluk agama sesuai dengan kepercayaan masing-masing. Negara menjamin kebebasan setiap orang untuk memeluk agama oleh karena inilah indonesia dikenal dengan negara pluralis.

Dalam pandangan filosofis sosial pluralis keadaan masyarakat yang dalam notabene berbeda-beda dalam tingkah laku, sudut pandang dan segala yang berkenaan dalam kehidupan kermasyarakatan. Kita lihat hubungan Islam dan pluralisme 
Komunike, Volume XI, No. 1, Juni 2019

memiliki dasar argumentasi yang konsep kesatuan umat yang kuat. Menurut Nurcholish Majid hal beriman. ${ }^{3}$

itu berangkat dari semangat Identik dengan istilah humanitas dan universalitas Islam. ${ }^{2}$ 'pluralisme' yang berarti 'beragam', Yang dimaksud dengan semangat pendapat orang tentang istilah ini humanitas adalah Islam merupakan juga beraneka ragam pula. Secara agama kemanusiaan (fitrah) atau harfiah pluralisme berarti jamak, dengan kata lain cita-cita Islam beberapa, berbagai hal, sejalan dengan cita-cita manusia keberbagaian atau banyak. Oleh pada umumnya. Dan misi Nabi karenanya sesuatu dikatakan plural Muhammad adalah untuk pasti terdiri dari banyak hal jenis, mewujudkan rahmat bagi seluruh pelbagai sudut pandang serta latar alam, jadi bukan semata-mata belakang. ${ }^{4}$

untuk menguntungkan komunitas Istilah pluralisme sendiri Islam saja. Sedangkan pengertian sesungguhnya adalah istilah lama universalitas Islam dapat dilacak yang hari-hari ini kian dari term al-Islam yang berarti mendapatkan perhatian penuh dari sikap pasrah pada Tuhan. dengan semua orang. Dikatakan istilah pengertian tersebut, semua agama lama karena perbincangan mengenai yang benar pasti bersifat al-Islam. pluralitas telah dielaborasi secara Tafsir al-Islam seperti ini bermuara lebih jauh oleh para pemikir filsafat pada konsep kesatuan kenabian Yunani secara konseptual dengan dan kerasulan, yang kemanusiaan aneka ragam alternatif dalam urutannya membawa kepada

2 Ahmad Amir Aziz. NeoModernisme Islam Di Indonesia (Jakarta: PT rineka cipta, 1999), hlm, 50.

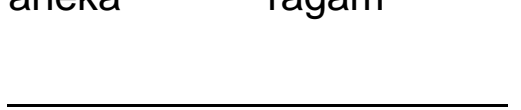
Pluralisme, Konflik dan Perdamaian Studi Bersama Antar Iman, (Yogyakarta: Pustaka Pelajar, 2002), hlm. 7. 
Komunike, Volume XI, No. 1, Juni 2019

memecahkannya. Para pemikir

tersebut mendefinisikan pluralitas

secara berbeda-beda lengkap

dengan beragam tawaran solusi mengubah paradigma lama yang menghadapi pluralitas. Permenides monolitik dalam doktrin agama, menawarkan solusi yang berbeda sosial, politik, dan lainnya yang dengan Heraklitos, begitu pula dibutuhkan untuk perdamaian dan pendapat Plato tidak sama dengan apa yang dikemu-kakan Aristoteles. ${ }^{5}$ Hal itu berarti bahwa isu pluralitas sebenarnya setua usia manusia.

Dalam khazanah kita dikenal dengan istilah "Bhineka Tunggal Ika" yang berarti berbeda-beda tapi tetap satu jua. Istilah ini untuk mendeskripsikan dan sebagai petunjuk bahwa akan keragaman bangsa Indonesia. Dalam istilah modern Bhineka (kemajmukan), ini kemudian sering diterjemahkan

\footnotetext{
${ }^{5}$ Perbincangan pluralisme menurut Amin Abdullah sesungguhnya tak lebih seperti put a new wine in the old bottle (memasukkan minuman anggur baru dalam kemasan lama). Baca M. Amin Abdullah, Dinamika Islam Kultural: Pemetaan Atas Wacana Islam Kontemporer, Bandung: Mizan, 2000), hlm 68 .
}

dengan pluralisme. Dalam wacana modernitas, pluralisme merupakan bentuk kesadaran baru yang mulai kerjasama serta menghilangkan prasangka dan truth claim.

Ada dua hal yang dapat meredam terjadinya konflik keagamaan yang dikemukakan oleh C. Geertz, toleransi yang didasarkan atas "relativisme kontekstual" dan pertumbuhan mekanisme sosial bagi bentuk integrasi sosial nonsinkretik yang majmuk, karena keduanya diibaratkan bagaikan dua sisi mata uang yang sama. ${ }^{6}$ Agama secara mendasar dan umum, dapat aturan dan peraturan yang

${ }^{6}$ Roland Robertson, Ed, Agama:

Dalam Analisa Dan Interpretasi Sosiologis,Terj, Ackhmad Fedyani Saifuddin, (Jakarta: Raja Grafindo Persada, Cet iv, 1995), hlm. 236. didefinisikan sebagai seperangkat 
Komunike, Volume XI, No. 1, Juni 2019

mengatur hubungan manusia Azyumardi Azra menjelaskan dengan dunia gaib, kehusus cara mengelola konflik: Pertama, dengan tuhannya, mengatur berkaitan dengan euforia hubungan manusia dengan manusia, kebebasan. Setiap orang atau dan mengatur manusia dengan kelompok merasa bisa dan dapat lingkungannya. Secara struktural- mengekspresikan kemauannya. Atas fungsional agama melayani nama kebebasan dan demokrasi kebutuhan manusia untuk mencari terdapat kalangan masyarakat yang kebenaran, mengatasi dan dengan mudah mengorbankan pihak menetralkan berbagai hal buruk lain melalui cara-cara kekerasan. 8 dalam kehidupannya. 7

Kedua, merebaknya fragmentasi Beragam konflik yang politik dan sosial khususnya melibatkan kelompok etnis dan dikalangan elite politik, sosial, agama masih saja berlangsung di militer, dan agama yang pada negeri ini. Konflik yang disertai gilirannya segera mengimbas ke tindakan kekersan (violence lapisan bawah (grassroot) dan conflict) tersebut melibatkan umat menimbulkan konflik horizontal yang dari satu agama yang sama luas. Terdapat berbagai indikasi, maupun berbeda agama belum konnflik dan kekerasan, bernuansa tuntas penanganan kasus perusakan agama bahkan diprovokasi kalangan sejumlah sarana ibadah dan tempat elite tertentu untuk kepentingantinggal. Konflik ini terjadi karena kepentingan mereka sendiri.

kita kurang memahami akan arti dari keberagaman dan kurang dikelola secara proposional.

8 Suprapto, Semerbak Dupa Di Pulau Seribu Masjid Kontestasi, Integrasi, Dan Resolusi Konflik Hindu-Muslim, (Jakarta:Prenadamedia Group, 2013), 7 lbid, hlm. v-vii. hlm. ix. 
Komunike, Volume XI, No. 1, Juni 2019

Ketiga, merosotnya penegakan dikutip dari zada. Di Indonesia hukum. Aparat keamanan dan terdapat lebih dari tiga ratus etnis. penegak hukum terlihat tidak Masing-masing etnis memiliki hannya mengalami friksi, konflik, budayanya sendiri dengan tetapi juga demokrasi sehingga menggunakan lebih dari dua ratus kehilangan kredibilitasnya dalam lima puluh bahasa. Selain diperkaya menegakkan hukum.

dengan agama asli penduduknya,

Keempat, meluasnya disorientasi hampir semua agama berada di dan dislokasi dalam masyarakat bumi nusantara ini. Coward indonesia, karena kesulitan-kesulitan menerangi, kemunculan setiap dalam kehidupan sehari-hari. Orang agama lahir dari lingkungan yang atau kelompok tertentu dengan plural dan membentuk dirinya mudah dan murah dapat sebagai tanggapan terhadap terprovokasi dan bahkan disewa pluralitas tersebut. Oleh sebab itu, untuk melakukantindakan-tindakan jika pluralitas agama tidak dipahami melanggar hukum dan kekerasan. ${ }^{9}$ secara benar dan arif oleh masingMasyarakat Indonesia masing pemeluk agama akan merupakan masyarakat plural. menimbulkan dampak, tidak hanya Keniscayaan diperoleh manakala berupa konflik antar umat ditinjau dari aspek yang beragama, tetapi juga konflik sosial melingkupinya, mulai dari etnis, dan disintegrasi bangsa. ${ }^{10}$ bahasa, budaya hinggaagama. Ini Pluralisme akan selalu menjadi artinya, pluralitas merupakan realitas menperbincangan yang terus bagi masyarakat indonesia. menurut mewancara khususnya dihadapan Heldred Geertz, sebagaimana

10 Zaenuddin, Pluralisme Agama Pergulatan Dialogis Islam-Kristen Di Indonesia, (Malang: UIN- Maliki Press, ${ }^{9}$ Ibid, $\mathrm{x}$. 2010), hlm. 1. 
Komunike, Volume XI, No. 1, Juni 2019

para akademisi selagi dunia ini baik dari segi agama, budaya masih dalam keadaan natural. la maupun suku jika di bandingkan berangkat dari post-modernisme dengan negara-negara lain. yang bercorak semrawut tetapi Terlebih lagi di pulau lombok yang kreatif dan berwatak merelatifkan terletak di provinsi NTB (Nusa segala apapun untuk mencapai Tenggara Barat), sebalah barat kebenaran inheren, sebuah berbatasan dengan pulau Bali, kebenaran yang tidak hannya sebelah timur berbatasan dengan dimiliki personal sebagai"yang pulau sumbawa, sebelah utara punya" tetapi mengakui bahwa berbatasan dengan laut jawa dan entitas diluar dirirnya memiliki hak sebelah selatan berbatasan dengan yang sama untuk menggapai samudra indonesia. Meskipun pulau kebenaran yang dipersepsikan ini terbilang kecil tetapi terdapat entitas yang satu dengan yang keberagaman agama, budaya, dan lain, sangat mungkin "lain" bahkan suku yang menjadikan keunikan tak jarang bertabrakan. ${ }^{11}$ tersendiri dari pulau tersebut. Di

Di Indonesia bukan hanya pulau lombok kita bisa menemukan terkenal dengan negara kepulauan beragam agama seperti; Islam, tetapi juga terkenal karena budha, hindu, konghuchu, kristen, keberagaman suku, budaya dan akan tetapi dari kesemua agama agama yang menjadikan indonesia tersebut agama hindu dan budha sebagai negara yang paling plural yang paling banyak berintraksi dan bergaul dengan masyarakat asli

11 Liza Wahyunianto Dan Abd. Qadir Muslim, Membuka Akar Pluralisme Agama; Mencari Isyarat-Isyarat Pluralisme Agama Dalam Al-Qur'an Dan Pelbagai Perspektif, (Malang: UIN-Maliki Press, gumi sasak yang mayoritas agama Islam bahkan bisa dibilang tidak ada jarak atau batasan dalam hal 2010), hlm. 1. 
Komunike, Volume XI, No. 1, Juni 2019

sosial kemasyarakatan berbeda Keling). Ada juga mengatakan halnya dengan kristen dan agama hindu, sedangkan agama konghuchu, yang selalu menjaga Islam masuk ke lombok pada abad batasan dalam hal sosial ke-7 $\mathrm{H}$. Dari pengaruh berbagai kemasyarakatan ini bisa dilihat dari pemahaman keagamaan yang ada hasil penelitian yang dilakukan oleh di lombok membuat masyarakat peneliti bahwa sejauh ini tidak ada lombok terkadang mengubahnya perkampungan khusus yang didalam menjadi keharmonisan dan tak perkampungan itu terjadi interaksi jarang mengubahnya menjadi dengan masyarakat asli gumi sasak konflik, seperti tragedi yang terjadi yang beragamakan Islam, mereka tahun 2001 pertikaian antara lebih memilih tempat-tempat agama Islam dan kristen yang perumahan khusus atau prumahan mengakibatkan kerugian antara (BTN), yang menyebabkan hal kedua belah pihak, baik dari faktor semacam ini, karena faktor ekonomi maupun tenaga. Konflik ini ekonomi, merasa sebagai didasari karena ada provokasi dari pendatang, ataukah karena pihak yang memiliki kepentingan stratifikasi sosial. yang mengatas namakan etnik

Jika kita melihat kembali agama.

sejarah sebelum masuknya Islam di Konflik yang mengatas namakan Lombok agama yang pertama kali etnik agama itu membuat kondisi dipeluk oleh masyarakat adalah masyarakat baik Islam maupun agama pagan sedangkan dalam kristen sama-sama mengalami takepan babat lombok menjelaskan kerugian. Benar kata peribahasa agama yang pertama kali dianut "kalah jadi abu menang jadi adalah agama Bodha (Budha arang". Pasca konflik, baik Islam 
Komunike, Volume XI, No. 1, Juni 2019

maupun kristen sama-sama

mengalami kerugian, mayarakat

Islam banyak kehilangan pekerjaan

yang semula bekerja di pabrik, atau

toko milik orang-orang yang

beragama kristen, sedangkan

agama kristen banyak mengalami

kehancuran baik rumah maupun

tempat ibadah bahkan waktu itu

terjadi pengusiran agama kristen di

Lombok terlebih di kota mataram

dan beberapa kecamatan yang ada

di Lombok Barat.

Konflik tersebut bersumber dari kelurahan cakra negara. kota mataram dimana tempat ini berkembang berbagai etnik agama yang semulanya hidup dalam keharmonisan, baik agama Islam, budha, hindu, kristen, kong hu cu, akan tetapi pasca konflik ada kesenjangan antara agama Islam dan kristen seolah-olah menjadikannya dilema tersendiri dari kedua etnik agama tersebut.

\section{B. Pengertian, Sejarah \\ Perkembangan Pluralisme Agama dan Budaya}

Peluralisme sendiri berarti keberagaman, sedangkan pluralisme agama adalah suatu pemahaman yang menganggap semua agama itu sama dan adanya kebenaran bagi semua agama. Pluralitas agama memang kenyataan yang tidak bisa dihindari bahkan masalah ini telah diakui dalam konstitusi dan telah ditegakkan adanya untuk masing-masing pemeluk agama untuk melaksanakan ajaran sesuai dengan keyakinan masing-masing. Meskipun halnya demikian pluralisme agama sebagai sebuah kenyataan sosial masih menimbulkan problematika dalam masyarakat bila dihadapkan dalam masalah teologi dan hak asasi manusia mengapa demikian? Di karenanakan setiap pemeluk agama menyakini bahwa ajaran agamanya harus ditegakkan dalam kehidupan bermasyarakat dan berbangsa. 
Komunike, Volume XI, No. 1, Juni 2019

Dalam hal ini agama sering sekali hal tersebut secara konseptual, dijadikan sebagai sumber konflik dengan aneka ragam solusi yang dalam masyarakat yang plural. ${ }^{12}$ dikemukakan. Solusi yang

Dalam pengertian lain juga ditawarkan Permenides berbeda dinyatakan istilah pluralisme sering dengan solusi yang disuguhkanoleh dikaitkan dengan sikap toleransi Heriklatos begitu juga solusi Plato dimana masing-masing agama, ras, berbeda dengan solusi yang suku, dan kepercayaan berpegang diberikan Aristoteles. ${ }^{14}$ Sedangkan pada prinsip masing-masing istilah pluralisme pada zaman Nabi kepercayaan dan menghorati Muhammad bukan hanya kepercayaan orang lain. ${ }^{13}$ dibicarakan secara konseptual tetapi Masyarakat harus menerima dilakukan secara realitas empiris, kenyataan bahwa disana tidak ada statement ini bisa dilihat dari kebenaran tunggal, artinya semua terbentuknya piagam madinah, kepercayaan itu benar. Atau tanpa masyarakat plural tidak akan masyarakat tidak boleh memiliki terbentuk piagam madinah yang keyakinan bahwa agama dan menjadi konstitusi masyarakat kepercayaan mereka itu paling madinah waktu itu. Pada waktu benar. piagam madinah dirumuskan dan Istlah Pluralisme itu disetujui, komunitas Islam masih sesungguhnya sudah dibicaraka oleh merupakan minoritas komunitas para pemikir sejak dahulu kala terbesar adalah komunitas yahudi falsafah Yunani telah membicarakan ditambah dengan komunitas kristen

12 Tarmizi Tahir, Dkk, Ham Dan Pluralisme Agama (Surabaya: PKSK, 1997), hlm. v.

${ }^{13}$ Hamid Fahmy Zarkasyi, Op. Cit, hlm. 138. dan penganut kepercayaan pagan.

${ }^{14}$ Amin Abdullah, Dinamika Islam Kultural: Pemetaan Atas Wacana Kelslaman Kontemporer (Bandung: Mizan, 2000), hlm. 68. 
Komunike, Volume XI, No. 1, Juni 2019

Nabi berperan sebagai pemersatu Nabi Muhammad, dalam dalam masyarakat yang plural, kapasitasnya sebagai bembuat the tanpa melebur kedalam satu maker law from new religion masyarakat yang tunggal. Dalam (pembuat hukum dari agama yang kesepakatan plural itu baru), banyak menciptakan aturandiproklamasikan terbentuknya aturan yang melegalkan hukumadat "masyarakat yang satu". Namun di dalam hukum Islam yang baru. dalam konstitusi yang merupakan Oleh karena itu Islam datang kontrak sosial (social contract) itu, memiliki misi dan visi untuk identitas kelompok tetap diakui, membawa rahmat bagi sekalian namun mereka bersepakat untuk umat dan alam semesta. Dunia membentuk solidaritas, inilah Islam sejak, awal perkembangannya hakekat pluralis yang merupakan sudah merupakan pluralitas dan reaktualisasi pluralitas di zaman oleh sebab itu mendekatinya klasik Islam. ${ }^{15}$ dengan pluralisme yang merayakan Begitu juga dalam keragaman sebagai rahmat. Dalam perjumpaannya dengan budaya lokal menghadapi realitas mengenai seperti mesir, maghribi, persia, pluralitas di dunia Islam telah india, turki, asia tengah dan cina, berkembang pluralisme oleh sebab penguasa-penguasa muslim tidak itu dalam dunia Islam terdapat memusnahka kebudayaan lokal berbagai macam kultur dan subkarena semua sesuai dengan apa kultur yang membentuk kesatuan yang pernah dilakunan oleh nabi pelangi Islam.

Dalam kehidupan sehari-hari Budhy Munawar-Rachman, Sekulerisme, Liberalisme Dan Pluralisme: Islam Progresif Dalam Perkembangan Dan Diskursusnya (Jakarta: PT Gramedia, manusia selalu dihadapkan dengan berbagai fenomena pluralitas. 2010), hlm. XLIX 
Komunike, Volume XI, No. 1, Juni 2019

Pluralitas warna kulit (kulit putih, manusia dalam memandang istilah hitam, kuning, sawo matang, dan pluralisme.

sebagainya), pluralitas etnik Dunia Islam sejak awal (tionghoa, arab, jawa, sunda, perkembangannya sudah merupakan bugis, sasak, bali, dan pluralitas oleh karena itu sebagainnya), pluralitas agama mendekatinya adalah dengan (kristen-katolik, kristen protestan, pluralisme yang merayakan hindu, budha, konghucu, Islam, keragaman sebagai rahmat. akan dan sebagainya) pluralitas bahasa tetapi pluralitas yang lahir di zaman (inggris, jerman, indonesia, jepang, modern ini memang berbeda mandarin, dan sebagainya). ${ }^{16}$ dengan pluralitas yang lahir Daftar pluralitas dapat diperpanjang sebelumnya, kebudayaan Islam sesuai dengan kehendak dan menjadi payung atau tenda besar kebutuhan yang ingin ditekankan terhadap kebudayaan-kebudayaan disini adalah isu pluralitas bukanlah lokal. Sekarang Islam sebagai barang baru, membicarakan kebudayaan, merupakan bagian dari pluraralitas sekarang ini adalah "to pluralitas global, dengan put a new wine in the old bottle" kebudayaan barat yang berintikan (memasukkan minuman anggur budaya yudeo-kristiani sebagai yang baru kedalam botol yang pemegang hegemoni yang lama), dalam arti isu pluralitas mendominasi. Hal inilah yang adalah setua usia manusia dan barangkali menjadi latar belakang selamanya akan ada dan akan resistensi sebagian umat Islam berkembang sesuai dengan ideologi (khususnya Islam-politik) terhadap

\footnotetext{
${ }^{16}$ A min Abdullah, Op. Cit, hlm.
}

69. 
Komunike, Volume XI, No. 1, Juni 2019

pluralisme modern. ${ }^{17}$ Kurangnya tuhan menjadi banyak agama satu eksistensi terhadap pluralitas dilatar tuhan. ${ }^{18}$

belakangi oleh beberapa persepsi; Di satu sisi, pemeluk semua Pertama, sementara pluralitas diakui agama atau penganut paham sebagai sunatullah, pluralisme keagamaan memiliki pandangan dianggap sebagai ancaman, yaitu bahwa tuhan adalah satu adanya ancaman bagi akidah. Pengakuan dan ajarannya paling sempurna dan terhadap pluraitas dianggap sebagai paling benar. Namun juga semua alat untuk melemahkan iman. orang, baik ia memeluk agama Kedua, pluralime dianggap sebagai tertentu atau tidak menyatakan ancaman terhadap identitas, sebab memeluk satu agama, memiliki dalam pluralisme, identitas akan kesadaran tentang tuhan. Pemeluk lebih ke dalam monlitas satu agama memiliki keyakinan masyarakat. Dasar pemikirannya bahwa agama yang dia peluk dalam pluralitas, kebenaran mutlak adalah itu yang paling benar dan akan digantikan kebenaran relatif. kebenaran itu hanya satu dan Kebenaran tidak lagi tunggal tunggal, yaitu yang diyakininya melainkan plural. Ini berarti dulu sendiri. ${ }^{19}$ Menyadari hal yang setiap agama menjadi pusat yang demikian bukan berarti akan dikelilingi tuhan, maka kini di ubah mencela kepercayaan agama lain tuhanlah yang dikelilingi agama, akan tetapi lebih menciptakan rasa artinya dari banyak agama banyak saling menghormati antar umat beragama ini juga bisa diartikan

\section{Hamid Fahmy Zarkasyi, Op.}

Cit, hlm. 142.

${ }^{19}$ Abdul Munir Mulkham, Satu Argumen Islam Untuk Liberalisme Islam Progresif Dan Perkembangan Diskursusnya (Jakarta: PT Gramedia, 2010), hlm. L. Tuhan Seribu Tafsir (Yogyakarta: Kanisius, 2007), hlm. 62. 
Komunike, Volume XI, No. 1, Juni 2019

pluralisme agama semua agama dan value vacuum. Secara implisit sama-sama valid yang berhak dan bahkan secara eksplisit, menilai kebenaran adalah Allah. relativisme juga mengandung arti

Jika dilihat kehawatiran umat bahwa seluruh pendapat, beragama pada umumnya dan pandangan dan keyakinan agamaterlebih-lebih umat Islam terhadap agama mempunyai nilai yang sama. pluralitas adalah pada akibat yang ditimbulkan dan konsekuensi

Kebebasan adalah karunia peraktis dari wujud pengakuan tuhan. maka kita tidak berhak formal tersebut terhadap paham mengungkung dan merampas "relativitas" keberadaan reltivitas kebebasan tersebut alasan mengapa adalah salah satu akibat dan tuhan menganugrahi manusia bahkan dapat dianggap saudara kebebasan, supaya manusi tulus kembar dari pluralitas. Pada dan ikhlas dalam beriman dan umumnya, umat beragama beragama. Itulah tujuan umum dari menganggap bahwa relativisme agama yang paling ideal dan mulia momok yang sangat ditakuti dan akan tetapi dalam wilayah empirissekaligus dijauhi dikarenakan praktis, niscaya tidak bisa membuat relativisme ${ }^{20}$ seolah-olah mesti keseragaman itu yakni di atas diidentikan dengan nihilisme moral dunia dan kehidupan dengan wajah

20 Pandangan bahwa tidak ada kebenaran atau nilai mutlak dan nilai itu ditentukan oleh zaman, kebudayaan, mayarakat dan pribadi tertentu. Relativisme murni (bahwa segala klaim kebenaran selalu relatif) sebenarnya bertentangan dengan nilainya sendiri. Bentuk relativisme yang lebih halus menekankan bahwa latar belakang sejara, kebudayaan, dan agama berperan dalam menetukan pemahan orang akan nilai kebenaran. tunggal dikarenakan sesungguhnya dalam ranah publik, sesuangguhnya sedang mengamalkan tradition. Kebenaran atas agama terletak pada pemahaman yang rasional

${ }^{21}$ Amin Abdullah, Op. Cit, hlm. 82. 
Komunike, Volume XI, No. 1, Juni 2019

dan dapat terpuji, yang akan mengkaji secara aktif, bijak dan membuktikan kebenaran sebuah cerdas yang pada gilirannya agama adalah sejarah. Kebenaran melahirkan dan merumuskan serta terletak pada sejarah yang teruji mengimplementasikan hakikat

penelitan dan karya ilmiah.

Menurut pendapat Tedius Batasina yang berbicara tentang agama (termasuk Islam di dalamnya):

"Mempertahankan independensi agama di tengah-tengah hiruk-piuk pergulatan zaman bukanlah suatu yang mudah semudah membalikkan telapak tangan. Nilai-nilai dormatif keagamaan sedang memasuki gerbang pergumulan yang amat sangat. Namun demikian, tidak ada alasan yang akurat untuk mengatakan bahwa agama-agama harus menghindari diri dari wilayah keperihatinan, namun justru sebaliknya, agama-agama harus membuktikan komitmen dan konsistensinya utuk menjaga kewibawaannya yang sakral dan tetap sadar menyimak, mengkritisi, panggilan misionernya".

$$
\text { Mungkin sekitar } 60 \text { tahun lalau }
$$

isu pluralisme atau keberagaman agama belum begitu akrab terdengar dikalangan masyarakat santri22 yang masih kuat dengan dogma kesantriannya sehingga tidak menerima pluralisme agama, akan tetapi untuk saat ini seiring dengan perkembangan zaman, sebagaimana seorang anak yang dikawal ketat orang tuanya serta masyarakat seagama. Tidak akan pernah bisa menghindar dari isu pluralitas agama yang banyak ditayangkan melalui media massa baik itu media cetak, visual maupun audio

\footnotetext{
22 Lihat. Clifford Geertz, The Religion Of Java (Illionis: Massachusetts Institute Of Technology, 1960). Terjemahan Indonesia, Aswab Mahasin dan Bur Rasuanto, Agama Jawa; Abangan, Santri, Proyayi Dalam Kebudayaan Jawa (Depok: Komunitas Bambu, Cet, Ke II, 2014), hlm. 181.
} 
Komunike, Volume XI, No. 1, Juni 2019

visual bahkan sekarang lebih menolak pluralisme agama, canggih lagi seperti media Internet. sebagaimana yang ditegaskan oleh Kenyataan empiris ini harusmenjadi Ismail Yusanto, juru bicara HTI, sorotan organisasi keagamaan bahwa pluralisme agama adalah kontemporer agar para koleganya absurd. Senada dengan Anis, tidak salah dalam mengambil Yusanto menegaskan, bahwa tindakan sosial kemasyarakatan. pluralisme agama adalah paham Di Indonesia sendiri istilah dari barat yang dikembangkan dari pluralisme agama menjadi marak teologi inklusif yang bertentangan diperbincangkan setelah di usung dengan QS. Ali Imran: 85 "barang oleh Nurcholis Madjid, Mukti Ali, siapa yang mencari agama selain Djohan Efendi. Dan pada tahun Islam, maka sekali-kali tidaklah terakhir ini dilanjutkan oleh generasi diterima dan di akhirat dia termasuk berikutnya. Budhy Munawar Rahman dengan Paramadinanya, Ulil Abshar oran-orang yang merugi". ${ }^{23}$ Abdalla dan kawan-kawan dengan yakin kebenaran hanya milik dan Jaringan Islam Liberalnya (JIL). Di monopoli umat Islam. kalangan agamawan Islam, baik Islam maupun kristen, pluralisme agama juga direspon dan dimaknai secara berbeda-beda (terdapat pro Dikalangan kristen, pandangan ini telah dikenal lama bahkan sejak abad pertama, sehingga dikenal ungkapan extra dan kontra) bagi kelompok Islam radikal seperti; Majlis Mujahidin ecclesiam nulla salus (tidak ada keselamatan di luar gereja).

Indonesia (MMI), Hizb Al-Tahrir Indonesi ( $\mathrm{HTI})$ dan Front Pembela Islam (FPI), dengan tegas mereka 
Komunike, Volume XI, No. 1, Juni 2019

Adapun tokohnya Karl Bath dan dijadikan suatu wadah untuk meraih Hendrick Kraemer dan pada kesuksesan dalam bermasyarakat umumnya para teolog evangelis. ${ }^{24}$ dan bernegara dengan menciptakan

Menepis setandar ganda dalam perbedaan untuk menjadi alat pemahaman seorang bagaikan membangun masyarakat yang lebih melawan arus sungai, setiap orang baek. Jangan kita hanya ribut-ribut pasti lebih meninggikan pemahaman tentang masalah furu'iyah saja apa yang telah dianutnya padahal tetapi masalah kesejahtrakan dalam ajaran agama, kita selalu masyarakat kita tidak pernah diajarkan sikap saling hormat memikirkannya. Allah menjelaskan menghormati dan toleransi antara dalam al-Qur'an “jika tuhanmu sesama umat beragama. Pluralisme menghendaki, niscaya dia agama jangan kita pahami secara menjadikan semua manusia sebagai negatif saja coba kita pahami satu kaum, tetapi mereka tetap secara positif. Keberagaman agama bercerai berai". ${ }^{25}$

suatu wadah yang menjadikan agama itu ada dan menjadikannya keseimbangan, tidak akan ada hitam kalau tidak ada putih begitupun halnya agama tidak akan ada agama Islam jika agama kristen, hindu, budha tidak ada, atau agama lainya. Masalah perbedaan seperti ini seharusnya

\section{Pluralisme Agama dan Pola Komunikasi Antar Umat Beragama}

Sebab-sebab lahirnya pluralisme agama adalah banyak dan beragam, sekaligus komplek. Namun secara umum dapat

\section{${ }^{25}$ QS. Hud. 118}

24 Zaenuddin, Pluralisme Agama

Dalam Analisis Kontruksi Sosial (Malang: UIN Maliki Press, 2013), hlm. 8. 
diklasifikasikan dalam dua faktor Dalam hal ini faktor idiologis atau utama yaitu internal (idiologis) dan aqidah terbagi menjadi tiga eksternal, yang mana faktor yang bagian: (1) Aqidah Ketuhanan, satu dan lainnya saling yaitu suatu keyakinan yang memepengaruhi, faktor internal mengakui akan adanya Tuhan merupakan faktor yang timbulakibat sbagai dzat yang maha segalatuntutan akan kebenaran yang galanya, yang harus dsembah dan mutlak dari agama-agama itu diyakini keberadaannya. sendiri baik dalam masalah aqidah, Aqidah "Keterpilihan", keyakinan sejarah maupun dalam masalah sebagai bangsa terpilih oleh Tuhan keyakinan. ${ }^{26}$ Faktor ini juga sering merupakan suatu aqidah yang dinamakan dengan faktor idiologis. hampir didapati dalam semua Adapun faktor yang timbul dari luar agama. Aqidah ini termasuk aqidah dapat diklasifikasikan ke dalam dua yang sangat peka dan berperan hal, yaitu faktor sosio-politis dan penting dalam pembentukan faktor ilmiah. Pertama, faktor kesadaran emosional suatu umat idiologis, keyakinan seseorang yang agama tertentu. Pada prinsipnya serba mutlak dan absolut bahwa aqidah ini lebih dikenal di kalangan apa yang diyakini dan diimaninya agama-agama samawi. itu paling benar dan paling Aqidah Pembebasan dan superior, adalah alami belaka. Keselamatan, konsep aqidah ini Keyakinan akan absolutisme dan pada dasarnya merupakan kemutlakan ini berlaku dalam hal konsekuensi logis dari konsep aqidah, madzhab dan idiologi. teologi ketuhanan dan teologi keterpilihan. Oleh karena konsep aqidah ini mempunyai hubungan

26 Ahmad Najib Burhan, Islam Dinamis, (Jakarta: Penerbit Buku Kompas, 2001) 4. 
Komunike, Volume XI, No. 1, Juni 2019

timbal balik yang sangat erat subur bagi berkembangnya teori dengan salah satu dari kedua pluralisme agama. yaitu faktor keyakinan tersebut di atas. Tidak sosio-politis. Di antara faktor yang dapat dipungkiri bahwa keyakinan mendorong munculnya teori terhadap suatu aqidah akan pluralisme agama adalah memberikan hak yang eksklusif berkembangnya wacana-wacana kepada seseorang atas pembebasan sosio-politis, demokrasi dan dan keselamatan. Dengan kata lain nasionalisme yang telah melahirkan seseorang yang ingin mencapai system ngara bangsa dankemudian keselamatan haruslah mengikuti mengarah kepada apa yang suatu system tertentu sebagai way sekarang ini disebut dengan of life. Keyakinan ini ada dan globalisasi yang merupakan hasil berkembang di setiap agama, baik praktis dari sebuah proses sosial agama yang mengakui Tuhan dan politis yang berlasngsung maupun agama yang tidak mangakui kurang lebih tiga abad. Proses ini Tuhan. Masing-masing mengklaim muncul semenjak pemikiran manusia keyakinannya yang paling benar, mengenal "liberalisme" yang sehingga menimbulkan sikap saling menyuarakan kebebasan, toleransi, menafikan. ${ }^{27}$ Kedua, faktor persamaan dan pluralisme. eksternal, disamping faktor faktor Liberalisme kemudian menjadi icon internal, terdapat juga faktor dan simbul setiap pergerakan eksternal yang kuat dan mempunyai sosio-politis dalam menentang peran kunci dalam menciptakan segala bentuk kezaliman dan iklim yang kondusif dan lahan yang kesewenang-wenangan. Hingga

27 Anis Malik Toha, Tren Pluralisme Agama: Tinjauan Kritis, (Jakarta: Gema Insani Press, 2005), 34. muncul dalam kamus sosial-politik suatu istilah yang disebut 
Komunike, Volume XI, No. 1, Juni 2019

"demokrasi." Proses liberalisme ini kemudian tidak lagi tidak terbatas hanya di Eropa saja akan tetapi menyebar keseluruh penjuru dunia dan menjadi fenomena global. Meskipun pada awalnya dasardasar liberalisme semula tumbuh dan berkembang sebagai proses sosio-politis dan sekular, akan tatapi pada akhirnya paham ini tidak hanya terbatas pada masalahmasalah politis belaka akan tetapi menjadi lebih universal yang didalamnya meliputi hak beragama dan berkeyakinan. Dalam hal ini agama kemudian tak berdaya lagi dan harus tunduk kepada kekuatan system di luar agama.

Istilah pluralisme sendiri bersal dari bahasa latin "pluralis yang berarti jamak. Lawan kata dari monisme, dualisme atau uniter. Pluralisme berarti suatu pandangan bahwa realitas itu tidak tunggal, tetapi berlapis secara independen dengan kebutuhannya masingmasing.
Jika pluralisme itu given, sementara konflik adalah sesuatu yang inhern di dalamnya. Pertanyaan selanjutnya bagaimana mengelola pluralitas dan konflik yang ada sehingga menjadi sebuah energi sosial bagi penciptaan tatanan bangsa yang lebih baik. Jawabannya tentu panjang dengan melibatkan pengkajian seluruh faktor yang ada. Akan tetapi terkait dengan kajian ini (memahami pluralitas), ternyata menjaga kerukunan tidak cukup hanya memahami keanekaragaman yang ada di sekitar kita secara apatis dan pasif. Memahami pluralisme meski melibatkan sikap diri secara pluralis pula. Sebuah sikap penuh empati, jujur dan adil menempatkan kepelbagaian, perbedaan pada tempatnya, yaitu dengan menghormati, memahami dan mengakui eksistensi orang lain, sebagaimana menghormati dan mengakui eksistensi diri sendiri. 
Komunike, Volume XI, No. 1, Juni 2019

Demikian juga dalam menyikapi pluralisme beragama. Sikap yang tercipta toleransi antar umat seyogyanya dilakukan seseorang beragama di Indonesia. adalah dengan memahami dan bahkan lebih jauh menyatakan menilai "yang" (agama) lain bahwa sejarah adalah lokus bagi berdasarkan standar mereka kehadiran asma-asama tuhan untuk sendiri serta memberi peluang bagi mengekspresikan dirinya dalam mereka untuk mengartikulasikan wajah budaya. Tak ada peristiwa keyakinannya secara bebas. Alwi budaya dan peristiwa sejarah tanpa Shihab, memberi gambaran cukup kehadarian dan keterlibatan tuhan di baik dalam mengartikulasikan plu- dalamnya. Budaya adalah tempat ralisme agama. Menurutnya, tuhan berinkarnasi melalui asma, "Pluralisme agama adalah bahwa kehendak dan ilmu-Nya untuk tiap pemeluk agama dituntut bukan mengaktualkan dirinya. Dan manusia saja mengakui keberadaan dan hak adalah agen tuhan yang orang lain, tetapi juga terlibat menghubungkan antara kehendak dalam usaha memahami perbedaan khalik di langit dan realitas makhluk dan persamaan, guna tercapainya di bumi. Oleh karena itu, akhlak kerukunan dalam kebhinekaan". ${ }^{28}$ manusia selalau mengorientasikan Melalui pemahaman tentang diri pada kualitas illahi di satu sisi pluralisme yang benar dengan dan berbuat baik pada sesama diikuti upaya mewujudkan kehidupan penduduk di bumi disisi yang lain. yang damai seperti inilah akan Dimana bumi bersifat feminin yang menunggu pembuahan dari langit

28 Alwi Shihab, Islam Inklusif: yang bersifat maskulin. Begitu juga Menuju Sikap Terbuka dalam Beragama, (Bandung: Mizan, 1999), cet. VII, hlm. agama mengandung dogma dan 340. 
Komunike, Volume XI, No. 1, Juni 2019

ajaran keselamatan yang jelas dan tegas, yang bersifat maskulin, namun ketegasan agama harus diformulasiakan oleh bahasa budaya yang penuh bijak, lembut, feminin, dan beradab. Oleh karenanya ketika agama bertemu dengan sebuah masyarakat yang tingkat peradabannya masih rendah, pesan mulia agama bisa terkalahkan oleh sikap-sikap mereka yang vulgar dan penyebarannya lalu mengandalkan kekuatan fisik, bukannya keunggualan intelek dan seni. ${ }^{29}$ Tradisi berbicara pada manusia bukan hanya melalui katakata tetapi juga bentuk seni yang lain. Pesannya tertulis bukan hanya pada buku dan dalam fenomena utama, tetapi juga terdapat pada bentuk karya tradisional dan khususnya seni suci. ${ }^{30}$

${ }^{29}$ M. Thoybi, Dkk, Sinergi Agama dan Budaya: Dialektika Muhammadiyah dan Seni Lokal, (Surakarta: Muhammadiyah University Press, 2003), hlm. 7.

30 Seyyed Hossein Nasr, Pengetahuan dan Kesucian, Terj,
Pada dasarnya, antara komunikasi dan kebudayaan merupakan dua hal yang tidak bisa dipisahkan. Pusat perhatian komunikasi dan kebudayaan itu terletak pada variasi langkah dan cara serta metode manusia berkomunikasi melintasi komunitas manusia atau kelompok sosial, bagaimana menjajaki makna, model tindakan dan bagaimana makna serta model-model itu diartikulasi sebuah kelompok sosial yang melibatkan interaksi antar manusia. sehingga komunikasi antarbudaya adalah komunikasi antara orang-orang yang berbeda kebudayaannya, misalnya antar suku bangsa, antar etnik, ras dan kelas sosial. ${ }^{31}$

Dalam komunikasi, komunikasi yang efektiflah yang akan mampu membangun proses komunikasi baik

Suharsono, (Yogyakarta: Pustaka Pelajar, 1997), hlm. 294.

$31 \quad$ Alo Liliweri.Dasar-dasar Komunikasi Antarbudaya, (Yogyakarta:

Pustaka pelajar,2009), hlm.10. 
Komunike, Volume XI, No. 1, Juni 2019

dan lancar antara komunikator dan komunikan. Pola komunikasi yang baik akan menunjang keefektian dari komunikasi yang akan maupun yang sedang berlangsung. Pola komunikasi adalah model, format, atau bentuk komunikasi yang dapat terlihat melalui bagai mana komunikator (baik individu maupun kelompok) mengkomunikasikan pesan-pesan komunikasi terhadap komunikan di dalam berintraksi.

Dengan adanya model komunikasi sekaligus dapat mereduksi fenomena komunikasi, artinya ada nuansa komunikasi lainnya yang mungkin terabaikan dan tidak terjelaskan oleh model tersebut. Berikut pengertian model komunikasi menurut beberapa ahli: 32

1. Model komunikasi merupakan deskripsi ideal mengenai apa

32 Deddy mulyana, IImu komunikasi: Suatu Pengantar, (Bandung: PT Remaja Rosdakarya, 2010), hlm. 132 yang dibutuhkan untuk terjadinya komunikasi.

2. Model komunikasi adalah analogi yang mengabstraksikan dan memilih bagian dari keseluruhan, unsure, sifat atau komponen yang penting dari fenomena yang dijadikan model.

Dari pengertian model komunikasi yang ada, maka peneliti menyimpulkan bahwa model komunikasi itu merupakan suatu penjelasan singkat yang berupa gambaran formal atas suatu fenomena komunikasi agar lebih mudah untuk dipahami dari pada teorinya.

Pola komunikasi dapat diliahat dan diamati dari berbagai macam aspek. ${ }^{33}$ Berdasarkan model komunikasi, Stewart L. Tubbs dan Sylvia Moss dalam buku Human Communication menjelaskan tiga model komunikasi yaitu: Model

33 Burhan Bungin. Sosiologi Komunikasi: Teory Pradigma dan Diskusi Teknologi Komunikasi, (jakarta: kencana, 2007), hlm. 253-254 
Komunike, Volume XI, No. 1, Juni 2019

komunikasi linier yaitu komunikasi satu arah (one-way view communication). Komunikasi dua makna pada lingkungan sekitar arah adalah komunikasi intraksional. melalui cara kita berintraksi dengan Model komunikasi transaksional, orang lain". ${ }^{35}$ Sedangkandramaturgi komunikasi yang hanya dipahami dalam konteks hubungan (relationship)antara dua orang atau lebih.

Pola komunikasi berdasarkan jumlah peserta yang terlibat dalam kominikasi yaitu: komunikasi intrapribadi, kominikasi diadik, komunikasi antarpribadi, komunikasi publik, komunikasi organisasi, dan kominikasi masa. ${ }^{34}$

Pola komunikasi dapat harus memahami simbol-simbol dalam berintraksi (intraksi simbolik) agar bisa mengefektifkan komunikasi. Dan juga dipresentasikan secara sedemikian rupa (dramaturg) sehingga menarik. Itarsionisme simbolik sediri dapat diartikan

\footnotetext{
34 Deddy mulyana, $\quad$ IImu komunikasi: Suatu Pengantar, (Bandung: PT Remaja Rosdakarya, 2010), hlm. 78.
}

sebagai "cara pelaku komunikasi menginterpretasikan dan memberi sendiri adalah pola komuniksai yang digunakan sebagai pengelolaan pesan untuk mencapai tujuan tertentu, sehingga dalam berkomunikasi dia menggunakan pola (gaya) tertentu untuk mengefektifkan komunikasi. Sehingga ada ungkapan "people are actors, structuring their performances to make impressions on audiences". ${ }^{36}$ Dalam komunikasi yang berlangsung. Komunikan dan komunikator saling memberikan pesan yang direspon baik secara verbal atau nonverbal, sadar maupun tidak komunikasi tersebut memberikan efek tertentu pada dan

35 Muhammad Mufid, Etika Dan Fisafat Komunikasi, (Jakarta: Kencana, 2010), hlm. 53.

\begin{tabular}{lcr}
\multicolumn{1}{c}{36} & Engkus & Kuswarno, \\
Fenomenologi, & (Bandung: & Widya \\
Padjadjaran, 2009), hlm. 116 &
\end{tabular}


Komunike, Volume XI, No. 1, Juni 2019

dapat merubah sikaf komunikan maupun komunikator.

Berdasarkan pembahasan tersebut maka model komunikasi antar budaya bisa dijelaskan secara sederhana melalui gambar brikut ini:

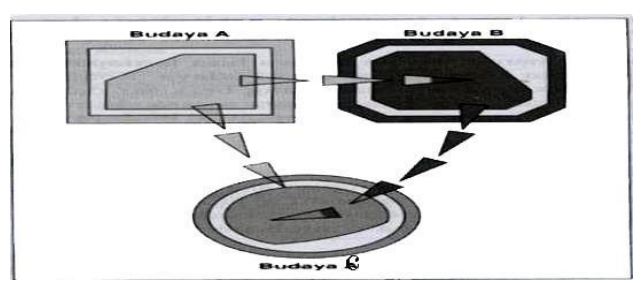

Gambar 1 Model Deddy Mulyana dan Jalalludin $\mathrm{R}^{37}$

Jika dilihat dari perilaku yang nampak pada proses komunikasi seseorang, bentuknya tidak akan $100 \%$ sama dengan bentuk budaya yang ia anut. Pengaruh budaya terhadap proses penyandian dan penyandian balik dalam komunikasi interpersonal terlihat pada gambar.

Gambar ini menunjukkan adanya tiga budaya yang berbeda yang diwakili oleh tiga bentuk geometric yang berbeda. Bentuk budaya $A$ dan budaya $B$ hampir

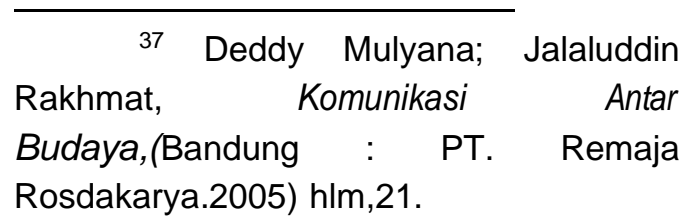

serupa, namun lain dengan budaya C yang bentuknya jauh berbeda.

Dalam setiap budaya ada bentuk lain individu yang agak serupa dengan bentuk budaya itu sendiri. Ini menunjukkan bahwa individu yang telah dibentuk oleh budaya. Bentuk individu sedikit berbeda dari bentuk budaya yang mempengaruhinya. Ini menggambarkan adanya pengaruhpengaruh lain di samping budaya yang membentuk individu dan sekalipun budaya itu dominant dalam mempengaruhi individu, orang-orang dalam suatu budaya pun memiliki sifat-sifat yang berbeda.

Sementara model Gudykunst dan Kim mengasumsikan bahwa dua orang yang terlibat dalam kegiatan komunikasi ini mempunyai kedudukan yang sama, sama-sama sebagai pengirim sekaligus penerima pesan, serta sama-sama melakukan enconding dan deconding. 
Komunike, Volume XI, No. 1, Juni 2019

Hal tersebut mengakibatkan menggambarkan bahwa ketiga factor pesan suatu pihak sekaligus juga ini saling berhubungan dan adalah umpan balik bagi pihak mempengaruhi. Selain itu, kedua lainnya yang ditunjukkan oleh individu yang terlibat juga terletak adanya garis dari penyandian dalam suatu kotak dengan garis seseorang kepenyandian balik orang putus-putus yang berarti mewakili lain dan dari penyandian orang pengaruh lingkaran. Hal ini sekali kedua kepenyandian balik orang lagi menggambarkan bahwa pertama. Sedangkan kedua garis lingkaran tersebut bukanlah suatu umpan balik ataupesan itu sistem tertutup.

menunjukkan bahwa setiap kita berkomunikasi, secara bersamaan kita melakukan penyandian dan penyandian balik. Dengan kata lain, komunikasi yang terjadi itu tidak statis.

Menurut Gudykunst dan Kim, penyandian dan penyandian balik terhadap pesan merupakan suatu proses interaktif yang dipengaruhi oleh filter-filter konseptual yang dikategorikan menjadi factor-faktor kultur, sosiokultur dan psikokultur yang nampak pada lingkaran dengan garis putus-putus. Garis putus-putus itu sendiri

\section{Makna peluralisme antar umat beragama}

Manusia di dunia telahir dengan fitrah (potensi beragama), ${ }^{38}$ sehingga bapak dan ibunya yang menjadikanya beragama Islam, Kristen, Hindu, dan Budha. Agama juga dikatakan sebagai candu rakyat (religion is the opium of the people) yang merupakan teks Karl Mark yang paling terkenal. ${ }^{39}$ Dalam kehidupan, agama sangat

${ }^{38}$ Abuddin Nata, Metodologi Studi Islam , (Jakarta: PT Raja Grafindo Persada, 2011), hlm. 5.

39 Muhammad Mufid, Etika Dan Fisafat Komunikasi, (Jakarta: Kencana, 2010), hlm. 51 
Komunike, Volume XI, No. 1, Juni 2019

penting bagi manusia karenaagama

mengukur makna dari

mengajarkan tentang nilai keberadaannya sendiri dan

kemanusiaan, kebaikan, dan jalan keberadaan alam semesta.

hidup yang senantiasa membimbing Degan asas skularisme ini manusia kearah yang lebih baik. ${ }^{40}$ masyarakat Sasak Lombok mampu

Agama sendiri berasal dari kata menciptakan keharmonisan dan "a" yang berarti "tidak", dan menciptakan pluralisme agama dan "gama" yang berarti "kacau". budaya menjadi indah. Sehingga Maksudnya, orang-orang yang tetap terjalin komunikasi antar umat memeluk suatu agama dan beragama, adapun strategi yang mengamalkan ajaran-ajarannya, digunakan yang masyarakat sasak hidupnya tidak akan kacau. Dalam menyebutnya "Panca Budaya bahasa Arab agama sering sebut Pluralis" antara lain:

din yang mengandung arti 1. Lewat budaya saling ajinin, menguasai, patuh, utang, maksudnya adalah budaya menundukan, balasan, dan saling menghargai saling kebiasaan. Adapun lain yang toleransi budaya sepeti ini bermakna agama adalah religi yang dapat terealisasikan dengan berasal dari kata relegare yang cara tidak menghina antar berarti mengikat. ${ }^{41}$ Menurut Elizabet kebudayaan dan memberikan K. Nottingham agama adalah usaha-usaha manusia untuk hak bagi para pemeluk agama untuk melakukan upacara kegamaan atau kebudayaan yang mereka yakini dengan Kerukunan, (Jakarta: Prenada, 2011), hlm. 16.

${ }^{41}$ Abuddin Nata, Metodologi Studi tidak menimbulkan Islam, (Jakarta: PT Raja Grafindo Persada, 2011), hlm. 9.

ketersinggungan antar pemeluk 
Komunike, Volume XI, No. 1, Juni 2019

agama dengan cara ini

Jika ada warga masyarakat masyarakat yang berbeda yang dapat musibah kematian agama dan budaya yang ada minsalnya musibah itu menimpa di Gumi Sasak dapat hidup salah satu warga dari rukun dan harmonis.

masyarakat Islam agama yang

2. Lewat budaya saling pesilaq, lain ikut melakukan maksudnya adalah budaya belasungkawa dengan cara saling "undang". Antara mengantarkan beras, ada juga pemeluk agama yang ada di yang memberikan uang dan hal Gumi Sasak (bumi Lombok) lain yang berupa materi demi selalu menjaga tradisi ini mengurangi beban yang diderita dengan tujuan untuk menjaga oleh warga yang terkena hubungan dalam bersosialisasi musibah tersebut.

dan bermasyarakat. Ketika

4. Lewat budaya saling ayowin, Agama Hindu mengadakan maksudnya adalah memelihara acara keagamaan atau ritual tali silaturrahmi "saling selalu melibatkan masyarakat kunjungi' kebiasaan ini yang agama yang nota bennya menjadikan terjalin keharmonisan berbeda begitu juga sebaliknya antara keberagaman agama dan berlaku bagi agama lain seperti budaya yang ada di Pulau Islam dan Buhda. Terkecuali Sasak.

ketia melakukan hal ibadah,

5. Lewat budaya saling jot, karena kepercayaan masingmaksudnya adalah "memberi masing agama berbeda.

makanan" lebih jelasya

3. Lewat budaya saling pelayarin, maksudnya adalah "melayat". menyuguhkan makanan oleh warga yang memiliki gawe 
Komunike, Volume XI, No. 1, Juni 2019

"hajatan" kepada warga yang dengan sebutan dalam bahasa berbeda agama. Minsalkan sasak disebut "empat ek" yang warga Hindu yang memiliki artinya empat cemohan yang harus gawe "hajatan", melakukan hal dijaga diantaranya:

yang tidak menyinggung agama

1. Nyadek "Minum-minuman

lain. Contoh: agama Hindu,

keras", bagi masyarakat Hindu demi menjaga rasa saling dan Budha ini sudah lumrah menghormati dan menghargai, bagi mereka mengkonsumsi warga yang memiliki hajatan maupun menjual untuk "gawe" menyerahkan sejumlah kalangannya, akan tetapi uang kepada orang Islam guna kebanyakan masyarakat yang untuk memblikan keperluan beragama Islam juga makanan yang sesuai dengan mengkonsumsi minuman ini syariat Islam, karena Islam sehingga ketika warga Islam memiliki aturan dan hukum melakukan pesta miras ditempat dalam mengkonsumsi makanan tersebut selalu mendapat yakni ada makanan yang teguran dan larangan diperbolehkan dan ada makanan yang di larang oleh agama. 42

Disamping itu juga ada empat hal yang perlu dijaga untuk mencegah terjadinya konflin antar agama dan menjaga hak-hak asasi antar umat beragama, dikenal

42 Wawancara, Djalaludin, Tokoh dikarenakan akan berdampak buruk bagi masyarakat Hindu dan Budha karena nanati mereka dianggap sebagai prokator jika terjadi keributan karena ada warga Islam yang mabuk dan membuat keributan ditempat itu.

Adat Lombok, Ketua Bidang Kebudayaan Sasak Di Lembaga Forum Komunikasi Antar Budaya, Hari Kamis, 09 Juli 2014. 
Komunike, Volume XI, No. 1, Juni 2019

2. Begocek "Sabung ayam" di keberlangsungan kerukunak, hususkan bagi masyarakat keberagaman antara umat beragama Hindu dan Budha, masyarakat dan budaya. yang beragama Islam tidak diperkenankan.

E. Kesimpulan

3. Ngubek "Berzina" dihususkan bagi masyarakat Hindu dan Budha, masyarakat yang beragama Islam tidak diperkenankan. karena takut akan menjadi keributan.

4. Ngorek "Mencuri wanita, kawin lari" dalam hal ini semua agama tidak boleh melakukan akan tetapi kebanyakan maryarakat "Islam yang ada di Lombok" senang melakukan hal seperti ini dan menjadi tradisi bagi masyarakat Islam Lombok. Akan tetapi tidak diperbolehkan mencuri wanita yang berlainan agama. $^{43}$

Keempat aturan ini harus dipatuhi demi menjaga

43 Wawancara, I Nyoman Sudarse, Tokoh Agama Hindu, Selasa, 07 Juli 2014.

Degan asas skularisme ini masyarakat Sasak Lombok mampu menciptakan keharmonisan dan menciptakan pluralisme agama dan budaya menjadi indah. Sehingga tetap terjalin komunikasi antar umat beragama, adapun strategi yang digunakan yang masyarakat sasak menyebutnya "Panca Budaya Pluralis" antara lain:

1. Lewat budaya saling ajinin, maksudnya adalah budaya saling menghargai saling toleransi budaya sepeti ini dapat terealisasikan dengan cara tidak menghina antar kebudayaan dan memberikan hak bagi para pemeluk agama untuk melakukan upacara kegamaan atau kebudayaan yang mereka yakini dengan 
Komunike, Volume XI, No. 1, Juni 2019

tidak

menimbulkan

ketersinggungan antar pemeluk

agama dengan cara ini

masyarakat yang berbeda

agama dan budaya yang ada

di Gumi Sasak dapat hidup

rukun dan harmonis.

2. Lewat budaya saling pesilaq, maksudnya adalah budaya saling "undang". Antara pemeluk agama yang ada di Gumi Sasak (bumi Lombok) selalu menjaga tradisi ini dengan tujuan untuk menjaga hubungan dalam bersosialisasi dan bermasyarakat. Ketika Agama Hindu mengadakan acara keagamaan atau ritual selalu melibatkan masyarakat agama yang nota bennya berbeda begitu juga sebaliknya berlaku bagi agama lain seperti Islam dan Buhda. Terkecuali ketia melakukan hal ibadah, karena kepercayaan masingmasing agama berbeda.
3. Lewat budaya saling pelayarin, maksudnya adalah "melayat". Jika ada warga masyarakat yang dapat musibah kematian minsalnya musibah itu menimpa salah satu warga dari masyarakat Islam agama yang lain ikut melakukan belasungkawa dengan cara mengantarkan beras, ada juga yang memberikan uang dan hal lain yang berupa materi demi mengurangi beban yang diderita oleh warga yang terkena musibah tersebut.

4. Lewat budaya saling ayowin, maksudnya adalah memelihara tali silaturrahmi "saling kunjungi' kebiasaan ini yang menjadikan terjalin keharmonisan antara keberagaman agama dan budaya yang ada di Pulau Sasak.

5. Lewat budaya saling jot, maksudnya adalah "memberi makanan" lebih jelasya 
Komunike, Volume XI, No. 1, Juni 2019

menyuguhkan makanan oleh warga yang memiliki gawe "hajatan" kepada warga yang berbeda agama. Minsalkan warga Hindu yang memiliki gawe "hajatan", melakukan hal yang tidak menyinggung agama lain. Contoh: agama Hindu, demi menjaga rasa saling menghormati dan menghargai, warga yang memiliki hajatan "gawe" menyerahkan sejumlah uang kepada orang Islam guna untuk memblikan keperluan makanan yang sesuai dengan syariat Islam, karena Islam memiliki aturan dan hukum dalam mengkonsumsi makanan yakni ada makanan yang diperbolehkan dan ada makanan yang di larang oleh agama.

\section{Daftar Pustaka}

Tarmizi Taher dan Moch. Basofi Soedirman, Ham Dan
Pluralisme Agama, (Surabaya: PSKS, 1997)

Ahmad Amir Aziz. Neo-Modernisme Islam di Indonesia (Jakarta: PT rineka cipta, 1999)

Syafa'atun Elmirzanah, Pluralisme, Konflik dan Perdamaian Studi

Bersama Antar Iman, (Yogyakarta: Pustaka Pelajar, 2002)

M. Amin Abdullah, Dinamika Islam Kultural: Pemetaan Atas Wacana Islam Kontemporer, Bandung: Mizan, 2000)

Roland Robertson, Ed, Agama: Dalam Analisa Dan Interpretasi Sosiologis, Terj, Ackhmad Fedyani Saifuddin, (Jakarta: Raja Grafindo Persada, Cet iv, 1995)

Suprapto, Semerbak Dupa di Pulau Seribu Masjid Kontestasi, Integrasi, Dan Resolusi Konflik Hindu-Muslim,

(Jakarta:Prenadamedia Group, 2013)

Zaenuddin, Pluralisme Agama

Pergulatan Dialogis Islam-

Kristen Di Indonesia, (Malang:

UIN- Maliki Press, 2010)

Liza Wahyunianto Dan Abd. Qadir Muslim, Membuka Akar Pluralisme Agama; Mencari Isyarat-Isyarat Pluralisme 
Komunike, Volume XI, No. 1, Juni 2019

Agama Dalam Al-Qur'an Dan Anis Malik Toha, Tren Pluralisme

Pelbagai Perspektif, (Malang:

UIN-Maliki Press, 2010) Budhy

Munawar-Rachman,

Sekulerisme, Liberalisme Dan

Pluralisme: Islam Progresif

Dalam Perkembangan Dan

Diskursusnya (Jakarta: PT

Gramedia, 2010)

Budhy Munawar-Rachman, Argumen

Islam Untuk Liberalisme Islam

Progresif Dan Perkembangan

Diskursusnya (Jakarta: PT

Gramedia, 2010)

Abdul Munir Mulkham, Satu Tuhan

Seribu Tafsir (Yogyakarta:

Kanisius, 2007)

Clifford Geertz, The Religion Of

Java (Illionis: Massachusetts

Institute Of Technology, 1960).

Terjemahan Indonesia, Aswab

Mahasin dan Bur Rasuanto,

Agama Jawa; Abangan, Santri,

Proyayi Dalam Kebudayaan

Jawa (Depok: Komunitas

Bambu, Cet, Ke II, 2014)

Zaenuddin, Pluralisme Agama

Dalam Analisis Kontruksi Sosial

(Malang: UIN Maliki Press, 2013)

Ahmad Najib Burhan, Islam

Dinamis, (Jakarta: Penerbit

Buku Kompas, 2001)
Agama: Tinjauan Kritis,

(Jakarta: Gema Insani Press, 2005)

Alwi Shihab, Islam Inklusif: Menuju

Sikap Terbuka dalam

Beragama, cet. VII

(Bandung: Mizan, 1999),

M. Thoybi, Dkk, Sinergi Agama dan Budaya: Dialektika

Muhammadiyah dan Seni Lokal,

(Surakarta: Muhammadiyah

University Press, 2003)

Seyyed Hossein Nasr, Pengetahuan

dan Kesucian, Terj, Suharsono,

(Yogyakarta: Pustaka Pelajar, 1997)

Alo Liliweri.Dasar-dasar Komunikasi

Antarbudaya, (Yogyakarta:

Pustaka pelajar,2009)

Burhan Bungin. Sosiologi

Komunikasi: Teory Pradigma dan Diskusi Teknologi

Komunikasi,

(Jakarta:

kencana, 2007)

Deddy Mulyana, Ilmu komunikasi:

Suatu Pengantar, (Bandung:

PT Remaja Rosdakarya, 2010)

Muhammad Mufid, Etika Dan

Fisafat Komunikasi, (Jakarta:

Kencana, 2010)

Engkus Kuswarno, Fenomenologi,

(Bandung: Widya Padjadjaran, 2009) 
Komunike, Volume XI, No. 1, Juni 2019

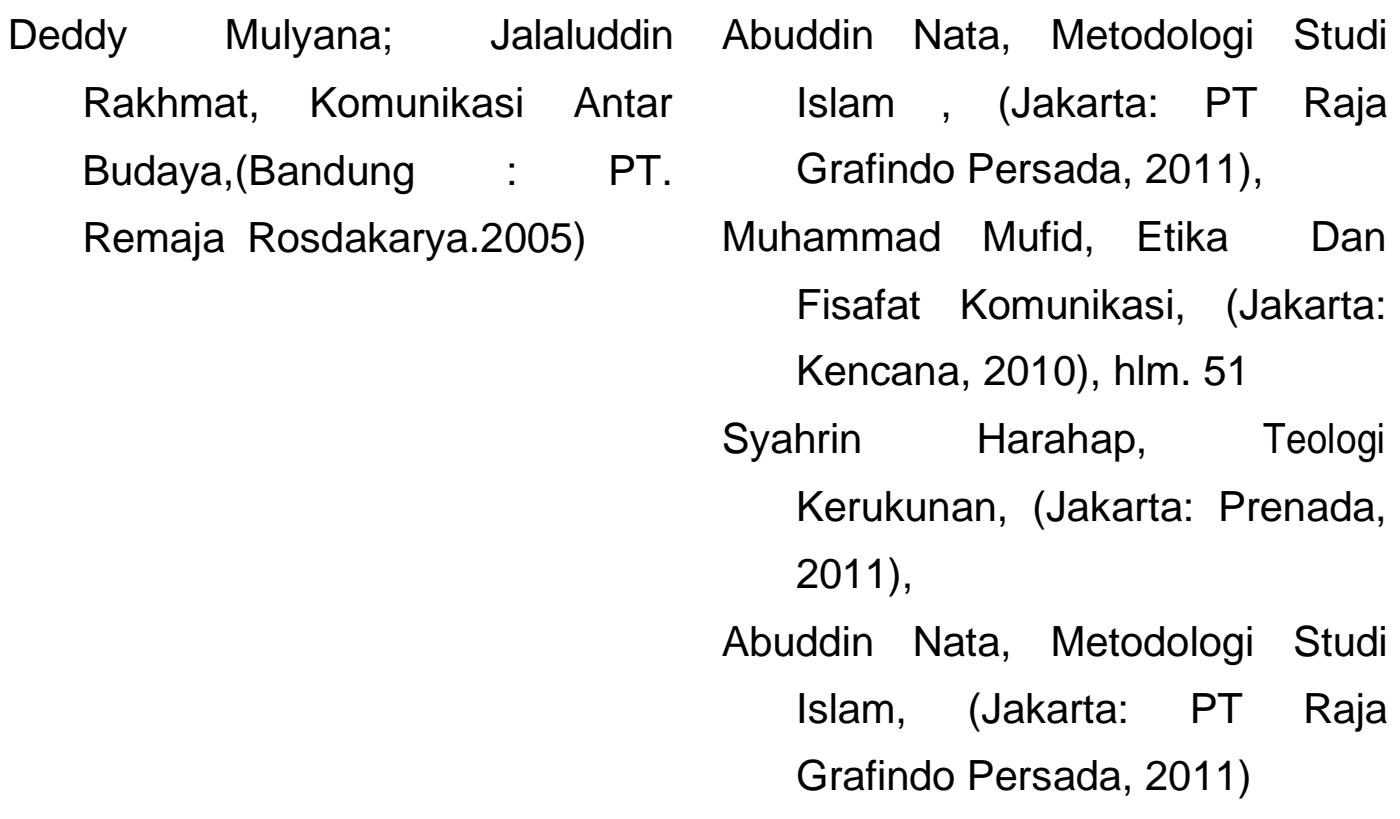

